\title{
Change of hand flora during the shift in emergency servise staff
}

\section{Acil servis çalışanlarında el florasının nöbet süresince değişimi}

\section{Sefa Yurtbay ${ }^{1}$, Yusuf Kenan Tekin² ${ }^{2}$ İlhan Korkmaz ${ }^{2}$, Fatma Mutlu Kukul Guiven ${ }^{3}$, Erdal Demirtaş ${ }^{2}$}

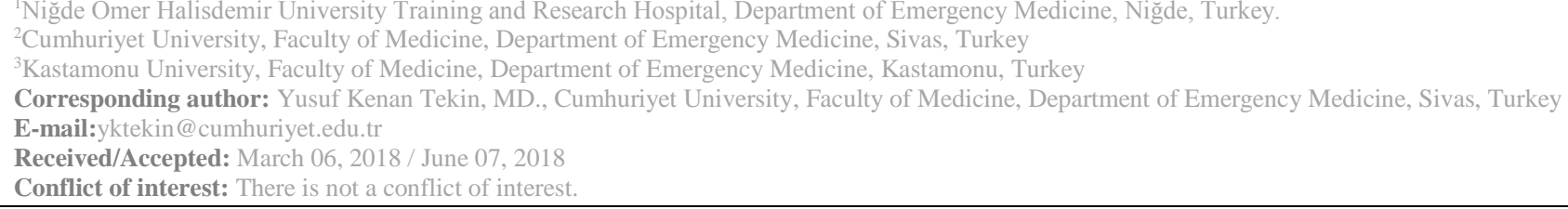

\section{SUMMARY}

Objective: We aimed to reveal the change in microorganisms in the hand flora during the working period from hospital personnels in the emergency department of Cumhuriyet University by taking hand cultures before and after the working period.

Method: Our study was planned to evaluate the change of the hand flora and pre-shift and post-shift hand cultures from 10 physicians, 13 nurses, 10 transport personnel in the emergency department of Cumhuriyet University. Also the microorganisms of air samples from special intervention areas (resuscitation, red area) as well as general use areas were analyzed.

Results: We compared the washing status between pre (4,\%11.1) and post-contact16 (44.4\%) hand washing rate. The volunteers generally had washed their hands after the contact with the patient and the difference was statistically was significantly higher $(\mathrm{p}<0.05)$. there wasn't any difference between the microorganisms samples that were reproduced on the pre-shift right and left hand samples and post-shift right and left hand. According to the total count of samples taken from the left and right hand before shift in terms of the microorganism seen the difference was significiant $(\mathrm{t}=7,48$; $\mathrm{p}=0,001)$.

Conclusions: Although our participants knew the hand hygiene indications of emergency service workers, their harmony was found to be low, consistent with many studies in the literature. It has been observed that the habit of using gloves and hand disinfectant was low also. Efficient strategies may be developed; improving institutional healthcare conditions, conducting educations at certain intervals, observing the practitioner and collecting feedback. However, it should be noted that the most significant issue is that the significance in hand washing is ensured with changes in habits.

Keywords: Hand hygiene, hospital-acquired infection control, hand washing, health workers, methicillin-resistant staphylococcus aureus.

\section{ÖZET}

Amaç: Çalışmamız Cumhuriyet Üniversitesi Tıp Fakültesi Hastanesi Acil servisimizde görev yapan hastane personelinden nöbet öncesi ve sonrasında el kültürleri alınarak nöbet süresince el florasındaki mikroorganizmlardaki değişimi ortaya koymayı amaçladık.

Yöntem: Çalışmamız, Cumhuriyet Üniversitesi acil servisinde görev yapan 10 hekim, 13 hemşire, 10 taşıma ve 7 temizlik personelinin nöbet öncesi ve sonrası her 2 elinden kültürleri alınarak el floralarındaki değişimleri değerlendirilmek üzere planlanmıştır. Ayrıca, özel müdahale alanlarındaki (resüsitasyon, kırmızı alan) hava numunelerindeki mikroorganizmalar araştırıld1.

Bulgular: Temas öncesi ve sonrası el yıkama oranları karşılaştırıldığında temas öncesi el yıkama oranı \%11.1(4), temas sonrası \%44.4(16,) olup farklılık istatiksel açıdan önemli bulunmuştur. $(p<0,05)$ Nöbet öncesinde alınan sağ ve sol el 
örnekleri ile nöbet sonrası alınan sağ ve sol elden alınan örneklemlerden üretilen mikroorganizmalar arasında herhangi bir fark bulunmadı. Nöbet öncesinde alınan sağ ve sol el örneklemeleri, üretilen mikroorganizmaların toplam sayıları açısından karşılaştırıldığında fark anlamlı olarak bulunmuştur. $(\mathrm{t}=7,48 ; \mathrm{p}=0,001)$.

Sonuç: Çalışmamızdaki sonuçları genel olarak değerlendirecek olursak hastanede el yıkama sıklığı ve süresinin uluslararası kılavuzlar ve belirtilen sınırlara yakın olduğu fakat temas öncesi ve sonrası el yıkama alışkanlığının beklenen düzeyde olmadığı saptandı. El yıkama davranışı ile ilgili eksiklerin giderilmesi açısından personelin eğitimi, uyumun kontrolü ve geri bildirimin yapılmasının etkili olacağı ortaya çıkmıştır. Yapılan hava örneklemleri değerlendirildiğinde tanımlanan bakteri çeşitliliği açısından alanlarda farklılık olmadığı ve bunların normal hava ortamında bulunan mikroorganizmalar oldukları tespit edilmiş oldu. Üreme sayıları açısından hasta bakımının daha fazla olduğu yeşil alanda ve sarı alanlarda daha çok üreme olduğu ortaya çıktı.

Anahtar sözcükler: El hijyeni, hastane kaynaklı enfeksiyon kontrolü, el yıkama, sağlık çalışanı, metisiline rezistans staphyloccus aerius.

\section{INTRODUCTION}

Definitions described as 'cross infection' or 'nosocomial infection' are healthcare-related infections. According to the World Health Organization (WHO) hand hygiene guideline, nosocomial infections affect millions of patients every year ${ }^{1}$. Healthcare-related infections are frequently encountered and are seen in both developed and developing countries. Healthcarerelated infections increase morbidity-mortality and hospitalization durations ${ }^{2-3}$. This leads to the physical and emotional affection of patients and their relatives, and also cause a high cost for the health system. In United States, it was reported that 1.7 million patients develop healthcare-dependent infection every year, and that 100,000 of these patients pass away, and also that there is an additional expense of \$ 5-7 billion every year ${ }^{4}$. Today, nosocomial infections are one of the leading causes of gradually increasing healthcare costs $^{5}$.

The nonadherence of clinical staff to hand hygiene has been identified to be a significant factor in dissemination of nosocomial infections. $30-40 \%$ of infections caused by hospital-originated resistant microorganisms are transmitted by the staff of hospitals 6. For example, considering that microorganisms on the hand of healthcare staff that come into contact with patients infected or colonized with MRSA are able to spread within 3 hours, the necessity and importance of handwashing is better understood ${ }^{2-3}$. It is considered that due to the nature of the functioning of the emergency departments in our country is more compliant with hospital-based aseptic techniques due to the difficulty, the pace and the intensity of the circulation

In our study, hand cultures were taken from the hospital staff working in our emergency department at the beginning and at the end of the working period. It is aimed to determine whether the hand flora will change and if any pathogenic microorganism growth will be occur during the working period.

Concurrently, after obtaining post-shift hand cultures, questions about hand hygiene were asked, aiming to evaluate awareness on hand hygiene among the personnel.

Thus, our objective was to have an opinion about if emergency department staff cause nosocomial infections in busy schedule, if patients that need hospitalized treatment are under risk of encountering pathogen microorganisms at the first clinical department, and if we, as healthcare professionals, take effect in contamination of ourselves, our families and patients that we are in close contact.

\section{MATERIAL AND METHODS}

This study was conducted at the Cumhuriyet University, Emergency Department. In our emergency department, we have two resuscitation fields and one field for interventions to patients with trauma, and in a great arena, there are fields categorized as red, yellow and green.

With an authorized laboratory technician assigned by the Department of Microbiology, the hand cultures were taken from 10 doctors, 13 nurses, 10 transportation personnel, 7 cleaning persons at the beginning and at the end of the working period in Cumhuriyet University emergency medicine department between 02.11.2016 -24.12.2016. At the same time, air samplings were taken from different areas in the emergency service. Bacteria growing by sampling on 5\% Sheep Blood Agar and EMB Agar plates incubated at $36{ }^{\circ} \mathrm{C}$ for $24-48$ hours were evaluated morphologically. The plaques with bacterial growth were evaluated microscopically by gram staining, classified as $\mathrm{Gr}$ $(+)$ and (-) coc and bacillus. Subsequently the bacterial colonies on the plates were identified by MALDI-TOF MS (Matrix-Assisted Laser Desorption / Ionization Time-of-Flight Mass 
Spectrometry) instrument. Staphylococcus aureus bacteria detected from the hands or the environment were evaluated if they were methicillin resistant or not.

For statistical analysis, data obtained from our study were uploaded to the SPSS (ver: 22.0) software, and since Mc Neman test in data evaluation and Chi-square assumptions were not fulfilled in grid layouts, Chi square value was calculated using the Monte Carlo model of Chi square Excut tests, and results were expressed as frequence and percentage in independent groups using significance test between two percentages, with an error level set at 0.05 .

\section{RESULTS}

Among the 40 emergency department staff volunteers in the study the mean age was $34.2 \pm$ $6.25(25-50)$ years. $33(82.5 \%)$ of the volunteers were male and $7(17.5 \%)$ female. $37(92.5 \%)$ were right-handed, and 3 (7.5\%) left-handed. The average working time of the participants in the emergency department, was found as $5.87 \pm$ 4.13(min1, $\max 16)$ years. According to their statement, the daily average hand washing frequency was $11.72 \pm 9.38 \mathrm{~min}(2-50)$. Again the average number of patients contacted during working hours was $29.07 \pm 15.85 \mathrm{~min}(2-60)$.

$10(25 \%)$ of the participating individuals stated to use hand antiseptic or alcohol several times during the working period, while 30 (75\%) remarked that they did not use any sanitizer for handwashing. 38 $(95 \%)$ of the individuals stated that they did not wear gloves before contact with the patient, $2(5 \%)$ of the volunteers stated that they wear gloves before getting contact with patients. While 4 (10\%) individuals pointed out that they regularly washed their hands before contact with patient, 36(90\%) stated that they did not. While 20(50\%) individuals stated that they washed their hands after contact with patient, $20(50 \%)$ individuals didn't. In general, when investigating the knowledge on WHO 5 basic hand washing indications, the participiants correct answer rate was $96.6 \%$.

Table 1: Comparison of hand washing before and after contact with the patient

\begin{tabular}{|l|l|l|l|l|l|}
\hline \multicolumn{2}{|l|}{$\begin{array}{l}\text { Comparison of hand washing before and after } \\
\text { contact with the patient }\end{array}$} & \multicolumn{2}{|l|}{ Hand washing after contact } & Total \\
\cline { 3 - 6 } & $\begin{array}{l}\text { Yes } \\
\mathrm{n}(\%)\end{array}$ & $\begin{array}{l}\text { No } \\
\mathrm{n}(\%)\end{array}$ & (n \%) \\
\hline $\begin{array}{l}\text { Hand } \\
\text { washing } \\
\text { before } \\
\text { contact }\end{array}$ & Yes & $\mathrm{n}(\%)$ & $4(100,0)$ & 0 & $4(100,0)$ \\
\cline { 2 - 6 } & $\mathrm{n}(\%)$ & $16(44,4)$ & $20(55,6)$ & $36(100,0)$ \\
\hline
\end{tabular}

While four of the 4 individuals washed their hands before and after getting in contact with a patient, 16 $(44.4 \%)$ of the 36 individuals stated that they washed their hands after contact and the remaining $20(55.6 \%)$ stated that they do not wash their hands.
When comparing hand washing status before contact and after contact, the difference was found to be statistically significant $(\mathrm{p}<0.05)$. 
Table 2: Microorganism Results of Air Sampling on 4 Different Days from Fields in Emergency Service

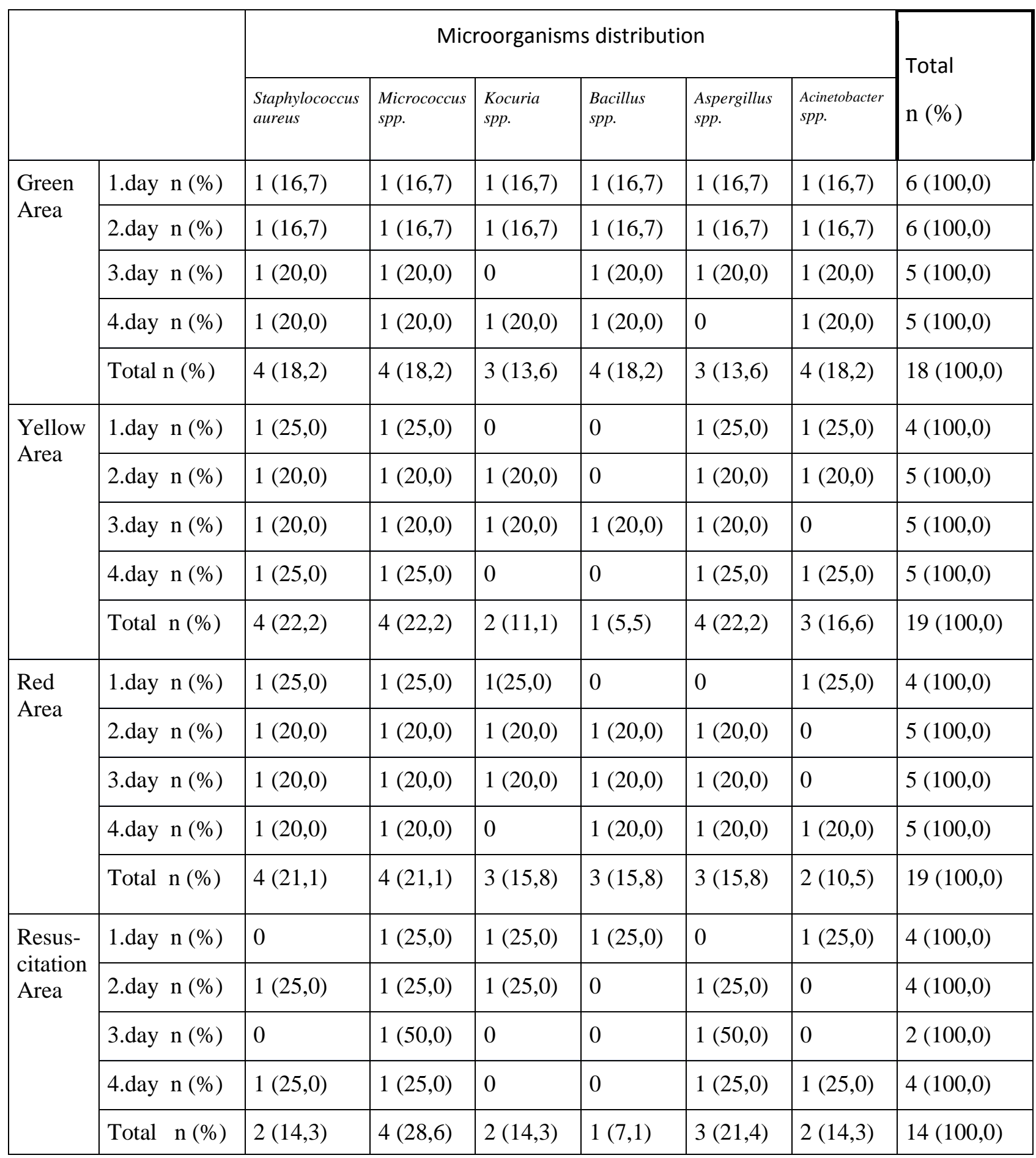

The distribution of the six different microorganisms was as follows; Staphylococcus epidermidis $18.2 \%(\mathrm{n}=4)$, Micrococcus species $18.2 \% \quad(\mathrm{n}=4)$, Kocuria species $13.6 \% \quad(\mathrm{n}=3)$, Bacillus species $18.2 \%(\mathrm{n}=4)$, Aspergillus species $13.6 \%(\mathrm{n}=3)$ and Acinetobacter species $18.6 \%$ $(\mathrm{n}=4)$ respectively.

In total, 6 different microorganisms growth was seen from the samples taken in the yellow field. while Staphylococcus epidermidis $22.2 \%$ (4),
Micrococcus spp. 22.2\% (4) and Aspergillus spp. $22.2 \%$ (4) were the mostly seen microorganism, Bacillus spp. 5.5\% (1) was the least one.

There are 6 different microorganisms observed in the samples taken from the red field of emergency department. The most common microorganisms were as follows: Staphylococcus epidermidis, $21,1 \%$ (4) Micrococcus spp.\%21,1'i (4). Least reproduction was seen in Acinetobacter sp. with $10.5 \%(\mathrm{n}=2)$. 
In the resuscitation area, six different microorganisms and a total of 14 bacteria were determined. The most reproduction was seen in Micrococcus sp. with $28.6 \%(\mathrm{n}=4)$, while least reproduction was seen in Bacillus sp. with $7.1 \%$ $(\mathrm{n}=1)$.
The microorganisms visualized from the right and left hands at the beginning and at the end of the shifts are shown in Table3.

Table 3: Right-Left hand microorganisms determined at the beginning and at the end of the working period

\begin{tabular}{|l|l|l|l|l|}
\hline & \multicolumn{2}{|l|}{ Right Hand } & \multicolumn{2}{l|}{ Left Hand } \\
\cline { 2 - 6 } & $\begin{array}{l}\text { Shift Onset } \\
\text { Right Hand } \\
\text { Sample n }(\%)\end{array}$ & $\begin{array}{l}\text { Shift End Right } \\
\text { Hand Sample n } \\
(\%)\end{array}$ & $\begin{array}{l}\text { Shift Onset } \\
\text { Left Hand } \\
\text { Sample n } \%)\end{array}$ & $\begin{array}{l}\text { Shift End } \\
\text { Left } \\
\text { Sample n }(\%)\end{array}$ \\
\hline $\begin{array}{l}\text { Staphylococcus. } \\
\text { Epidermidis }\end{array}$ & $40(31,3)$ & $39(29,1)$ & $40(29,9)$ & $39(30,0)$ \\
\hline Micrococcus spp. & $32(25,0)$ & $36(26,9)$ & $35(26,1)$ & $32(24,6)$ \\
\hline Kocuria spp. & $1(0,8)$ & $3(2,2)$ & $1(0,7)$ & $1(0,8)$ \\
\hline Bacillus spp. & $24(18,8)$ & $27(20,1)$ & $23(17,2)$ & $27(20,8)$ \\
\hline Aspergillus spp. & $9(7,0)$ & $7(5,2)$ & $12(9,0)$ & $11(8,5)$ \\
\hline Acinetobacter spp. & $14(10,9)$ & $13(9,7)$ & $12(9,0)$ & $13(10,0)$ \\
\hline Corynebacterium spp. & $1(0,8)$ & $2(1,5)$ & $1(0,7)$ & - \\
\hline Moraxella spp. & $1(0,8)$ & - & $1(0,7)$ & $1(0,8)$ \\
\hline Wautersiella spp. & $1(0,8)$ & - & $1(0,7)$ & - \\
\hline $\begin{array}{l}\text { Staphylococcus } \\
\text { Aureus }\end{array}$ & $5(3,9)$ & $4(3,0)$ & $4(3,0)$ & $4(3,1)$ \\
\hline Streptococcus spp. & - & $2(1,5)$ & $1(0,7)$ & $1(0,8)$ \\
\hline $\begin{array}{l}\text { Staphylococcus } \\
\text { Succinus }\end{array}$ & - & $1(0,7)$ & - & $1(0,8)$ \\
\hline E. Coli & $128^{*}(100)$ & $134^{*}(100)$ & $134 *(100,0)$ & $130 *(100,0)$ \\
\hline $\begin{array}{l}\text { Staphylococcus } \\
\text { pasteuri }\end{array}$ & & & $1(0,7)$ & - \\
\hline Serratia liquefaciens & & & $1(0,7)$ & - \\
\hline Total & & & & - \\
\hline
\end{tabular}

*Percentages were taken according to the total number of microorganisms growth 
Table 4: Comparison of microorganisms and primates determined at the beginning of the working period

\begin{tabular}{|l|l|l|l|}
\hline Microorganism species & \multicolumn{2}{|c|}{ Hand } & Total \\
\cline { 2 - 4 } & $\begin{array}{l}\text { Right hand before } \\
\text { working period } \\
\mathrm{n}(\%)\end{array}$ & $\begin{array}{l}\text { Left hand before } \\
\text { working period } \\
\mathrm{n}(\%)\end{array}$ & $\mathrm{n}(\%)$ \\
\hline $\begin{array}{l}\text { Staphylococcus } \\
\text { Epidermidis }\end{array}$ & $40(31,3)$ & $40(29,9)$ & $80(30,5)$ \\
\hline Micrococcus spp & $32(25,0)$ & $35(26,1)$ & $67(25,5)$ \\
\hline Kocuria spp & $1(0,8)$ & $1(0,7)$ & $2(0,7)$ \\
\hline Bacillus spp & $24(18,8)$ & $23(17,2)$ & $47(17,9)$ \\
\hline Aspergillus spp & $9(7,0)$ & $12(9,0)$ & $21(8,0)$ \\
\hline Acinetobacter spp & $14(10,9)$ & $12(9,0)$ & $26(9,9)$ \\
\hline Corynebacterium spp & $1(0,8)$ & $1(0,7)$ & $2(0,7)$ \\
\hline Moraxella spp & $1(0,8)$ & $1(0,7)$ & $2(0,7)$ \\
\hline Wautersiella spp & $1(0,8)$ & $1(0,7)$ & $2(0,7)$ \\
\hline Staphylococcus Aureus & $5(3,9)$ & $4(3,0)$ & $9(3,4)$ \\
\hline Streptococcus spp & - & $1(0,7)$ & $1(0,3)$ \\
\hline E. Coli & - & $1(0,7)$ & $1(0,3)$ \\
\hline Staphylococcus pasteuri & - & $1(0,7)$ & $1(0,3)$ \\
\hline Serratia liquefaciens & - & $134 *(100,0)$ & $262(100,0)$ \\
\hline Total n(\%) & $128^{*}(100,0)$ & $p>0,05$ & \\
\hline & $X^{2}=6,300 p=0,958$ & \\
\hline
\end{tabular}

There was any significiant difference between the right and left hand microorganism species that were determined at the beginning of the working period. The total number of bacteria that reproduced on the left and right hand at the beginning working period was $262.128(48,8 \%)$ of them were determined from the right, and 134
$(51,2 \%)$ from the left hand. When comparing the total count of samples between the left and right hand before shift, a statistically significant difference was found $(t=7.48 ; \mathrm{p}=0.001 ; \mathrm{p}<0.05)$. 
Table 5: Comparison of microorganisms and primates determined at the end of the working period

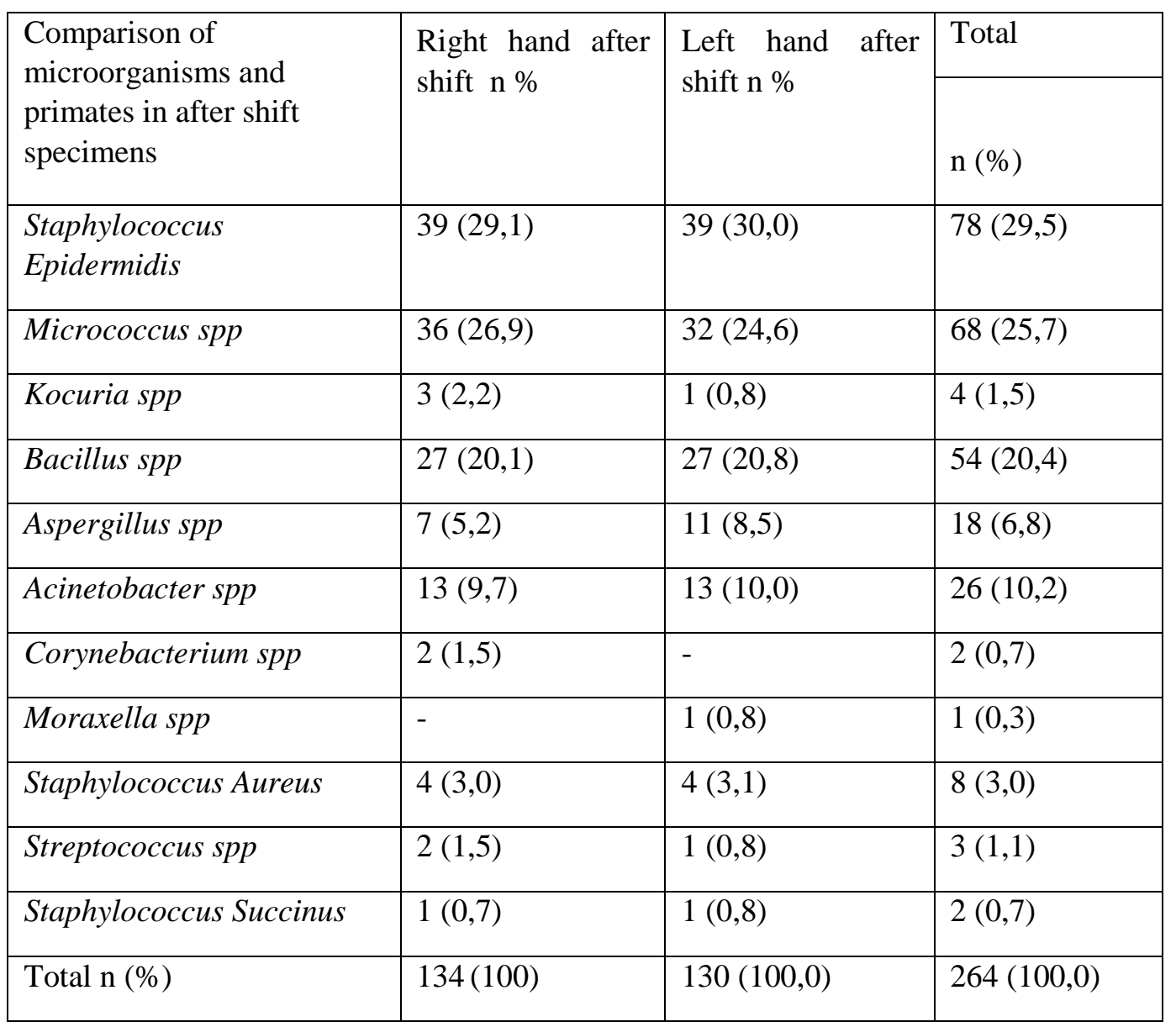

$X^{2}=5,897, p=0,880$

When comparing the microorganisms that reproduced on left and right hand at the end of working period samples, no significant difference was found. The total number of bacteria determined at the end of the working time were $264,134(50,7 \%)$ reproduced on the right right hand and $130(49,3 \%)$ on the left hand. When we

\section{DISCUSSION}

Healthcare related infections, i.e. nosocomial infections, are a serious health problem. Nosocomial infections lead to prolonged hospitalization, increase in treatment costs, development of antibiotic resistance, and even death. Hand hygiene is a simple, but efficient method made individually to prevent in-hospital dissemination of resistant pathogens and decrease nosocomial infection rates.

Antiseptic agents are agents applied on the skin in order to decrease the number of microorganisms in the transient flora. The necessity of hand antiseptic usage along with water and soap in hand hygiene compared microorganism samples rate between the left and right hand after the working shift, a statistically significant difference was found $(\mathrm{t}=7,82 ; \mathrm{p}=0,001 ; \mathrm{p}<0,05)$.

has been explained since the the beginning of the $21^{\text {st }}$ century. Whereas a study by Kuzu et $\mathrm{al}^{7}$, detected that most of the healthcare professionals (99.3\%) used only liquid soap in hand washing. In our study, it was found that $10(25 \%)$ individuals used hand antiseptic, and that $30(75 \%)$ individuals didn't used, resulting in a low rate of usage of hand antiseptic. It was concluded that this might be explained with the fact that hand antiseptics are difficult to access and previous education programs were unsuccessful in alteration of behavior.

In a study conducted in a neonatal intensive care unit, it was reported that the number of microorganisms and colonies on the hands of healthcare staff increased by $24.5 \mathrm{CFU} / \mathrm{cm}^{2}$ when 
they used not gloves during caregiving to infants. It was stated that wearing gloves decreases, but not eliminates microbial contamination on the hands, and it was also emphasized that hand hygiene even between applications on the same patient is very necessary ${ }^{8}$. In our study, 2 participants $(5 \%)$ were identified to touch with gloves, and the glove usage rate was found low.

In many studies, various rates have been identified about adherence to hand washing rules. WHO states that the adherence to hand hygiene by healthcare staff is very $l_{0}{ }^{3}$. While in a study by Arda et al. ${ }^{9}$ of 1286 contact cases, the adherence rate to hand hygiene rules was at 5.3\%, Erasmus et al. ${ }^{10}$ systematically investigated 96 studies on adherence to hand hygiene guideline in patient care, and found it among the healthcare staff as $40 \%$. In a study by Freeman et al., 11298 contact cases were evaluated and adherence to hand hygiene was reported as $65 \%{ }^{11}$. Concerning this issue, two studies conducted in our country reported the adherence rate to hand hygiene in different values, as $20.8 \%$ and $75 \%$, respectively ${ }^{5,12}$. In our study, adherence of the individuals to hand hygiene was found low as $30 \%$. As seen in our study and in other studies, adherence to hand washing indications of individuals working at healthcare facilities is low. This may be explained with busy work schedules in the emergency department, excessive workload and decrease of adherence in cases where critical care is needed.

It was stated that adherence to hand hygiene was higher in dirty and high risk procedures due to the tendency of primary self-protection of the healthcare-staff 7,11 . In our study, it was detected that only 4 individuals washed their hand both before and after contact with patients, and that 16 individuals washed their hands after contact. Difference between pre-contact and post-contact hand washing has been found to be statistically significant $(p<0.05)$. This result suggests that the behavior of self-protection by healthcare professionals increased the rate of post-contact hand washing.

It was shown that $30 \%$ of nosocomial infections can only be prevented with hand hygiene ${ }^{4,13}$. The World Health Organization suggests to use multidirectional strategies to increase adherence to hand hygiene, launching national campaigns on this issue ${ }^{5}$. Efforts for development of hand hygiene led to serious decreases of healthcare related infections both in the intensive care unit and the hospital ${ }^{14}$. Lam et $\mathrm{al}^{14}$; have established a problem-based, hand washing training program among health care workers after observing and identifying factors related to non-compliance with hand washing; by monitoring the patient contact frequency, hand washing practices and technique of health workers. Afterwards, they observed the hand washing practice after 6-month education of the staff and reevaluated them. The rates of hand washing before patient contact increased from $40 \%$ to $53 \%$, after patient contact from $39 \%$ to $59 \%$, during high risk procedures from $35 \%$ to $60 \%$, and also the infection rates in the intensive care unit decreased. Jamal et al. ${ }^{15}$ reported that adherence to hand hygiene in the pediatrics hospital increased from $23 \%$ in 2006 to $87 \%$ in 2011 through a multimodal quality improvement approach for increasing adherence to hand hygiene. It was stated that strong leadership, sharing, hand antiseptics that are easily accessable in patient care, multidirectional education programs, observing, hand hygiene application suggestions and regular feedbacks are all efficient in attempts of multimodal quality improvement.

Based on the fact that microorganisms in settings where healthcare is provided are a factor of nosocomial infections, air samples achieved in areas of the emergency department resulted in detection of reproduction of Staphylococcus epidermidis, Micrococcus spp., Kocuria spp., Bacillus spp., Aspergillus spp. and Acinetobacter spp. However, by the means of variety of detected bacteria, it was seen there was no difference and that these are microorganisms that are found in usual air settings. The lack of detection of pathogenic microorganisms in the air samples showed that our emergency service had adequate ventilation system.

With regard to number of reproduction of microorganisms, it was seen that there was more reproduction in green and yellow areas, where more patient care is seen (Table 2). In a case report published in our country ${ }^{16}$, it was reported that Kocuria varians bacteremia was seen in a patient with a diagnosis of multiple myeloma. Due to the significant risk of nosocomial infection in general emergency setting in immune suppressed patients, it may be considered that rooms with special isolated ventilation systems are needed in emergency departments.

When comparing the microorganisms reproducing from the left and right pre-shift and post-shift samples of the participating emergency department staff, no statistically significant difference was found, while the difference of the total number of reproducing microorganisms was found to be statistically significant, with a higher reproduction 
number on the right hand (Table $4, \mathrm{X}^{2}=6.85$, $\mathrm{p}=0.870, \mathrm{p}>0.05$, not significant; Table $5, \mathrm{X}^{2}=$ $7.89, \mathrm{p}=0.653, \mathrm{p}>0.05$, not significant).

Our study aimed to observe the various hygienic behaviors of the emergency service workers and the variation of the microorganism in the hand flora during the working period.

Limitations: We consider that our study has various limitations; we did not compare hand washing techniques and agents, and instead of observation, we took the statements of the staff of hand washing habits in consideration.

\section{CONCLUSION}

There were no similarities found between the distributions of microorganisms detected in our study and the nasocomial microorganisms that cause nosocomial infections. Even so we need to increase the adherence to hand hygiene. It may be suggested that efficient strategies may be developed; improving institutional healthcare conditions, conducting educations at certain intervals, observing the practitioner and collecting feedback. However, it should be noted that the most significant issue is that the significance in hand washing is ensured with changes in habits.

\section{REFERENCES}

1. World Health Organization. Guidelines on Hand Hygiene inHealthcare. Geneva: WHO Press; 2009.

2. Pittet D, Allegranzi B, Storr J, Donaldson L. Clean care is safer care: the global patient safety challenge 2005-2006. Int J Infect Dis. 2006; 10(6): 419-24.

3.Boyce JM, Pittet D. Guideline for Hand Hygiene in Health-Care Settings. Recommendations of the Healthcare Infection Control Practices Advisory Committee and the HICPAC/SHEA/APIC/IDSA Hand Hygiene Task Force. Society for Healthcare Epidemiology of America/Association for Professionals in Infection Control/Infectious Diseases Society of America. MMWR Recomm Rep. 2002; 51(RR-16):1-45.

4. Allegranzi B, Storr J, Dziekan G, Leotsakos A, Donaldson L, Pittet D. The first global patient safety challenge "Clean care is safer care": from launch to current progress and achievements. J Hosp Infect. 2007; 65(Suppl. 2): 115-23.

5. Sevim Şen1, Meral Sonmezoğlu2, Elif Akbal3, Esra Uğur4, Sibel Afacan1 Bir Universite
Hastanesinde Sağlık Personelinin El Hijyeninde Beş İndikasyona Uyumu.2010.

6. Akdeniz S. Yoğun bakım infeksiyonlarının önlenmesinde hemşirenin rolü, s: 149-59. Köksal İ, Çakar N, Arman D (eds), Yoğun Bakım İnfeksiyonları. 2005. Bilimsel Tip Yayınevi, Ankara.

7. Kuzu N, Ozer F, Aydemir S, Yalcin AN, Zencir M. Compliance with hand hygiene and glove use in a university-affiliated hospital. Infect Control Hosp Epidemiol. 2005; 26(3): 312-5.

8. Pessoa-Silva CL1, Dharan S, Hugonnet S, et al. Dynamics of bacterial hand contamination during routine neonatal care. InfectControl Hosp Epidemiol. 2004; 25(3): 192-7.

9. Arda B, Şenol Ş, Işıkgoz Taşbakan M, et al. Ege Universitesi Tıp Fakultesi Yoğun Bakım Unitelerinde el temizliği kurallarına uyumun değerlendirilmesi. Yoğun Bakım Dergisi. 2005; 5: 182-6.

10. Erasmus V, Daha TJ, Brug H, et al. Systematic review of studies on compliance with hand hygiene guidelines in hospital care. Infect Control Hosp Epidemiol. 2010; 31(3): 283-94.

11. Freeman J, Sieczkowski C, Anderson T, Morris AJ, Keenan A, Roberts SA. Improving hand hygiene in New Zealand hospitals to increase patient safety and reduce costs: results from the first hand hygiene national compliance audit for 2012. N Z Med J. 2012; 125(1357): 178-81.

12. Keşaplı M, Cete Y, Kartal M. Acil serviste el yıkama davranışının ozellikleri ve etkileyen faktorler. Türkiye Klinikleri Tıp BilimleriDergisi. 2004; 24(3): 235-42.

13. Guner R. Oncelik hangisinde? El hijyeni. Hastane İnfeksiyonları Dergisi. 2011;15: 110-2.

14. Lam BC, Lee J, Lau YL. Hand hygiene practices in a neonatal intensive care unit: a multimodal intervention and impact on nosocomial infection. Pediatrics. 2004; 114(5): e565-71.

15. Jamal A, O'Grady G, Harnett E, Dalton D, Andresen D. Improving hand hygiene in a paediatric hospital: a multimodal quality improvement approach. BMJ Qual Saf. 2012; 21(2): 171-6.

16. Multipl Myelomlu Bir Hastada Kocuria varians Bakteriyemisi, Hava Üsküdar Teke, Samet Karahan Kayseri Eğitim ve Araştırma Hastanesi, Hematoloji Kliniği, Kayseri, Türkiye Klinik Dergisi 2012; 25(3): 125-6 